\title{
Mesoscale variation in reproduction, recruitment and population structure of intertidal mussels with low larval input: a bay/open coast comparison
}

\author{
C. D. McQuaid*, T. E. Phillips \\ Department of Zoology \& Entomology, Rhodes University, Grahamstown 6140, South Africa
}

\begin{abstract}
Several studies suggest invertebrate recruitment is affected by coastal configuration, implying effects on population structure. Mesoscale (1 to $100 \mathrm{~km}$ ) variability in spawning and recruitment of intertidal mussels was examined at 12 sites on the South African south coast. There were 3 shore types: Algoa Bay shores (sandstone) and open coast shores (sandstone or dune rock). Timing of spawning and recruitment did not differ among shore types, but intensity did. All shores had continuous spawning and trickle recruitment, with peak periods. Spawning at each shore peaked 3 to 4 times per year with poor synchrony among sites, even sites only 3 to $4 \mathrm{~km}$ apart. Spawning correlated negatively with air and sea temperature, being most likely in winter/spring. Individual gamete output was greater in Algoa Bay. Recruitment was poorly pulsed and much lower than in most boreal studies; 1 to 2 juvenile cohorts appeared on each shore each year, with no synchrony among shores. Each cohort recruited over 2 to 3 mo. Subsequent mortality and growth were density independent, which suggested that pre-settlement factors are important in population regulation. New cohort densities correlated with spawning intensity, and were significantly greater in Algoa Bay. Spawning intensity, new cohort density, growth and mortality accounted for $76 \%$ of the variation in recruitment into adult populations (multiple regression). Differences in spawning and recruitment were associated with differences in population size structure and adult longevity. Mesoscale differences in recruitment and a spawning output/new cohort density correlation can be accounted for by limited dispersal of larvae on scales of tens of kilometres, with open coast and Algoa Bay populations acting as semi-discrete elements of a metapopulation.
\end{abstract}

KEY WORDS: Mussels · Recruitment - Intertidal communities · Population dynamics · Larval dispersal $\cdot$ Perna perna $\cdot$ Metapopulation $\cdot$ Spawning

\section{INTRODUCTION}

Variability in the intensity of recruitment of benthic organisms, especially of sedentary animals onto hard substrata, influences the relative importance of density-dependent and density-independent effects on population structure. At lower recruitment rates, the importance of competition for space among sessile organisms should become negligible in community regulation (Connell 1985, Menge \& Sutherland 1987). Thus, when settlement rates are low, population size should theoretically be controlled largely by presettlement factors that influence the availability of lar- vae. Post-settlement factors, including interspecific and intraspecific competition, should be of greater importance where settlement rates are high (see reviews by Booth \& Brosnan 1995, Underwood \& Keough 2001). If settlement rates are high enough to lead to intraspecific competition, then adult and settler densities will not be correlated because competition reduces growth and increases mortality (Connell 1985); we refer to this as 'uncoupling' of adult and recruit densities. Thus, both the abundance and size structure of the population are likely to be strongly influenced by larval settlement rates (Roughgarden et al. 1985, Alexander \& Roughgarden 1996); however, 
this hypothesis assumes that all larvae are of similar quality (cf. Jarrett \& Pechenik 1997).

Settlement refers to the permanent contact of a planktonic larva with the substratum (Keough \& Downes 1982). It can involve metamorphosis (Seed \& Suchanek 1992) and forms the transition from planktonic to benthic life (Poulin et al. 2002). Recruitment is essentially the number of individuals that survived a certain period of post-settlement mortality, and recruitment rate can be defined as the rate at which juveniles join the population (Pineda 2000). The control of recruitment thus consists of 2 filters: pre- and postsettlement factors. Pre-settlement factors include larval availability and settlement success. Availability depends on spawning intensity (if dispersal is low), fertilisation success, dispersal, larval mortality and hydrographic supply to the site. Settlement success is dictated by the availability of suitable habitats and larval behaviour, as well as competence. Post-settlement factors are biotic or abiotic mortality. Recruitment success will be regulated at the post-settlement level only if settlement rates are high. However, the timing of recruitment can be critical (Underwood \& Fairweather 1989). For example, synchrony of settlement at a site is important, as there can be windows of time when larval supply is heavy, leading to greater importance of post-settlement factors than if the same number of recruits appeared over a protracted period (Connell 1985).

Few studies make direct comparisons of settlement or recruitment rates among biogeographic regions, i.e. regions characterised by distinctly different biotas and environmental conditions (Booth \& Brosnan 1995); though this is changing at least within countries/coastlines (e.g. Connolly \& Roughgarden 1998, Harris et al. 1998, Broitman et al. 2001). There often appears to be a strong geographic component to the intensity of settlement that presumably partly reflects variation in the intensity of primary production, as this affects the availability of food to larvae. For example, chlorophyll levels decrease enormously from the west coast of South Africa to the east coast (Brown 1992) and this is reflected in differences of 4 orders of magnitude in mussel recruitment rates (Harris et al. 1998). Likewise, Guichard et al. (2003) found mussel recruitment to be greater on the upwelling-dominated west coast of New Zealand than the east coast. Patterns of settlement vary among taxa (Keough 1983), but most boreal, temperate studies of barnacles and mussels involve rather intense, relatively synchronised settlement (e.g. Raimondi 1990, Petraitis 1991, Caceres-Martinez et al. 1993). At lower latitudes, predictability and synchronisation of invertebrate reproduction and settlement are often poorer (Keough 1983, Sutherland 1990, Lasiak \& Barnard 1995, Koh et al. 2005, McQuaid \& Lawrie
2005), possibly because primary production tends to be less strongly pulsed (Lalli \& Parsons 1993). As a result, pre-settlement factors - including dispersal-are expected to be more important at lower latitudes. Examples emphasizing the importance of competition and predation come from areas with heavy recruitment (e.g. Suchanek 1978, Branch 1984, Menge 1991, Seed \& Suchanek 1992).

In many studies, settlement rates have also been shown to vary considerably over a wide range of spatial scales ( $\mathrm{cm}$ to $\mathrm{km}$ ) within the same biogeographic region (Petraitis 1991, Bertness et al. 1992, Hunt \& Schiebling 1996 and many others). More importantly, while actual settlement rates are unpredictable, sites separated on scales of kilometres or less often show consistent ranking by intensity of settlement, implying consistent differences in larval supply (e.g. Connell 1985, Sutherland 1990, Porri et al. 2006) that may reflect the influence of local oceanography on intertidal processes (Gaines \& Bertness 1992, Connolly et al. 2001, Menge et al. 2003). On scales of tens of kilometres, variability in the abundance of larvae depends partly on regional gamete production and partly on the scales of dispersal of larvae, which can uncouple reproduction from recruitment, so that there is no correlation between gamete production and recruitment in a population. Modelling of benthic populations as demographically 'open' explicitly assumes that dispersal results in 'local' reproductive rates that have no bearing on the control of 'local' population sizes (Caley et al. 1996). At such scales or larger, exchange of larvae among populations results in a metapopulation of interlinked local populations (Caley et al. 1996, Thorrold et al. 2002).

The openness of benthic populations thus depends on the effective dispersal distance of propagules, which varies from place to place, time to time, and among taxa. In the present study, we examined whether mesoscale (1 to $100 \mathrm{~km}$ ) variability occurred in the reproductive output of intertidal mussels in the same biogeographic area. We then considered whether variations in spawning intensity were correlated with variations in recruitment and population structure. To do this, we compared shores separated by 5 to $150 \mathrm{~km}$ in a large bay and on the open coast on the south coast of South Africa.

\section{MATERIALS AND METHODS}

Study sites. Shores in the Algoa Bay region of South Africa are of 2 rock types. Semi-consolidated aeolian dune rock forms wave-cut platforms with an abrupt drop-off at the seaward edge, while sandstone forms ridges and gulleys running perpendicular to the shore- 
line and sloping at 15 to $20^{\circ}$. Algoa Bay shores are all sandstone, both rock types occur on the open coast. We compared spawning, recruitment and population structure of intertidal mussels on 3 types of shore: Algoa Bay (sandstone), open coast sandstone and open coast dune rock. Timing, intensity and duration of spawning were studied at 6 sites. Recruitment intensity and population size structure were studied at these and a further 6 sites. Sites were randomly selected to represent the 3 shore types (Fig. 1). Wind and air temperature data were obtained from hourly measurements at Port Elizabeth Airport, $\sim 5 \mathrm{~km}$ from the coast. Sea surface temperature was taken from twice daily measurements in Port Elizabeth. Mean tide levels were calculated from published tide tables.

General approach. Mussel populations in the area primarily comprised 2 species. Perna perna predominated at 10 of the 12 shores studied, forming between 91 and $>99 \%$ of mussel numbers. Choromytilus meridionalis was the most abundant mussel species at 2 shores in Algoa Bay, where it formed $90 \%$ of total numbers. The 2 species are similar in size and show habitat segregation: $C$. meridionalis occurs in sandinfluenced and P. perna in sand-free areas (Marshall \& McQuaid 1993). Comparisons of individual gamete output showed no difference between the 2 species (see below) and, for this study, we have considered them together as 'mussels', separating them only where indicated.

Spawning. Because a large portion of mussel gonad is almost inextricably combined with the digestive gland (Griffiths 1977), direct measurements of gonad weight were not feasible for large sample sizes. However, changes in body weight of South African mussels are associated with gametogenesis and spawning, as the weight of other body parts does not vary seasonally (Griffiths \& King 1979, authors' unpubl. data). We used changes in length/weight relationships to identify spawning events at each site. To do this, monthly samples of 50 individuals (30 to $80 \mathrm{~mm}$ long) were selected randomly from the middle of the mussel zone. Maximum shell length was measured to $1 \mathrm{~mm}$. The shells were opened by heating in water; sex was noted from the colour of the gonad, and the flesh was removed and dried to constant weight $(0.01 \mathrm{~g}$ precision $)$ at $60^{\circ} \mathrm{C}$. Length/weight regressions were calculated for each sample for each site and used to estimate the weight of a standard-sized mussel of $65 \mathrm{~mm}$, the largest size that is commonly found on these shores (McQuaid et al.

2000). When this showed a significant decrease among samples at a site (see below), we assumed that this represented a period when a large proportion of the population had spawned and regarded this as a spawning event. This is less precise than histological examination, but allows much larger sample sizes to be measured and has been used successfully to identify spawning events confirmed by histological analysis (Van Erkom Schurink \& Griffiths 1991, authors' unpubl. data).

Samples were collected monthly from 6 sites between April 1989 and July 1990 (16 samples per site), except for one site (Three Sisters, TS) where sea conditions prevented sampling in winter (June and July) 1990. Sampling continued at bimonthly intervals at Swartkops (SW), Brighton Beach (BB) and Kenton (KE, see Fig. 1) until May 1991 (a further 5 samples per site).

Analysis of spawning data. Pooled samples from all sites and each mussel species had a male to female ratio that did not differ significantly from 1 ( $\chi^{2}$ test, $\mathrm{p}>$ 0.05). In a preliminary study, we examined the gonads and found no differences in reproductive state and no significant difference between sexes in the weight of similarly sized mussels (Mann-Whitney $U$-test, p > $0.05, \mathrm{n}=100$ in each case). Subsequently, data for the 2 sexes were pooled. Dry weight was regressed against shell length for each site for each month. The weight of a standard individual was calculated from regressions and used for comparisons among sites and 
months. This allows examination of changes in condition based on large samples, but estimates of the weight of standard animals are unreplicated and comparisons among months are difficult because of the huge number of regressions. Therefore, to identify spawning events, we used analysis of covariance (ANCOVA) to test for differences in slopes among monthly regressions at each site. All sites showed significant differences (ANCOVA, $\mathrm{p}<0.005$ in all cases). This was followed by multiple range tests comparing slopes and, if these were not significantly different, the intercepts of the regressions for the months before and after a suspected spawning event. A spawning event was defined as a period when a standard individual lost weight between 2 consecutive samples and the 2 length/weight regressions showed a significant difference in slope or intercept. Spawning intensity was estimated as gamete output, measured as the decline in weight of a standard individual during spawning. The probability of spawning each month was calculated as the number of sites where spawning occurred as a proportion of the number of sites sampled.

Recruitment. Recruitment and population size structure were monitored by destructive sampling of triplicate quadrats $(12.5 \times 12.5 \mathrm{~cm})$ from random positions in the middle of the mussel zone. Mussels $>25 \mathrm{~mm}$ often had traces of gonad material and were regarded as mature. Mussels $<20 \mathrm{~mm}$ were referred to as 'recruits' and separated into 'early juveniles' (<10 mm) and 'juveniles' (10 to $19 \mathrm{~mm}$ ). Mussels greater than $20 \mathrm{~mm}$ were regarded as adults and were measured individually to the nearest millimetre. Smaller mussels were sorted into size classes of 0.0 to $4.9,5.0$ to $9.9,10.0$ to 14.9 , and 15.0 to $19.9 \mathrm{~mm}$ and counted. We used the densities of early juveniles $(<10 \mathrm{~mm})$ to study recruitment through cohort analysis.

Cohort analysis. Cassie's (1954) method was used to identify cohorts and estimate their mean size and density from monthly size frequency histograms. This was complicated by continuous 'trickle' recruitment over extended periods and the difficulty of identifying discrete cohorts where settlement rates were especially low. Only cohorts that could be clearly identified and tracked until they died out or merged with older cohorts were used in the analysis. Growth and mortality of individual cohorts, and of all cohorts pooled, were estimated by regression analysis of mean size against time and of cohort density against time. Recruitment intensity was estimated as the maximum density of a newly settled cohort, and recruitment into the adult population as density of the same cohort after 10 mo on the shore, when most individuals in the cohort had reached maturity (see below).

Statistical analysis. One-way ANOVA was used to test hypotheses of inequality in dependent variables (recruitment intensity, spawning intensity, adult densities) among the 3 shore types (Algoa Bay, open coast sandstone, and open coast dune rock), using shore type as a fixed factor. All data were tested for normality (Kolmogorov-Smirnov test) and homoscedasticity (Bartlett's test and Cochran's C-test) before analysis. Data on monthly densities at each site failed the test for homoscedasticity, even after transformation, and were examined using Kruskal-Wallis tests.

Possible relationships between environmental factors (duration and mean velocity of the 4 main wind directions, sea and air temperature, mean tidal height) and either spawning or recruitment were examined using cross-correlation analysis. Seasonal decomposition of the data (Dunstan 1993) was used to remove the general and seasonal components from the time series of changes in weight of a standard individual. This left the residual monthly fluctuation in body weight that represented weight loss due to spawning. Analyses were carried out using lag periods of 0 to 6 mo to explore possible relationships between environmental factors and (1) recruit density (2) residual fluctuations in body mass. Cross-correlation with zero lag was used to examine synchrony in spawning and recruitment among sites.

Multiple regression analysis was used to examine the effects of 4 independent factors on recruitment into the adult population at the 6 sites where spawning was measured. The factors examined were spawning intensity (weight loss during spawning), intensity of recruitment (density of early juvenile cohort), growth (change in mean size of cohort) and mortality prior to maturity (decrease in cohort density). The probability of first-order autocorrelation among the independent variables was tested by calculating the Durban Watson statistic. Where appropriate, results are presented as mean values.

\section{RESULTS}

\section{Spawning}

There was a significant positive relationship between dry weight and shell length at all sites in all months, with a Bonferroni corrected $\alpha$ value of 0.0005 . Coefficients of determination generally ranged between 0.70 and 0.99 , dropping below this in only 4 out of 109 regressions. ANCOVA (with shell length as the co-variate) showed that for each site there were significant $(p<0.005)$ differences among slopes for monthly regressions. Similarly, the weight of a standard individual of $65 \mathrm{~mm}$ estimated from these regression equations fluctuated with time at each site (Fig. 2). These fluctuations in body mass were associated with 
changes in the size and colour of the gonad. Recently spawned animals were of low weight and had only traces of unshed eggs or sperm.

Periods when a standard individual showed a drop in weight were examined for each site by comparing the slope of the regression before the drop in weight with that for the following sample. In only one comparison was a non-significant difference in slope coupled with a significant difference in intercept. Significant differences indicated a change in the length/ weight relationship and were taken to indicate spawning events. These occurred 3 to 4 times per year at each site, but the timing of these events varied among sites. Cross-correlation with no lag period indicated occasional significant correlations between sites, but these were not related to the distance between the sites (see Fig. 4). e.g. spawning at Kwaiihoek was significantly correlated with that at Kenton (4 km east) but not Diaz Cross (4 km west). Spawning was significantly correlated between Three Sisters and Brighton Beach (>100 km apart).

Spawning could take place in any month (Fig. 3), but the probability was greater in winter and spring (May to October), with a low probability in midlate summer (January to March). There were no significant correlations with any lag period between the probability of spawning and the heights of low tide or high tide, wind velocity or the frequency of the 2 most common winds (NE or SW). Spawning was inhibited (significant negative correlation with zero lag) by high air and sea temperatures $(r=-0.67$ and -0.72 respectively, $p<$ 0.05 for both; Fig. 3A,B) and by frequent SE winds 1 mo earlier $(r=-0.71, p<0.05$, lag period of 1 ; Fig. $3 C$ ). High temperatures and SE winds are both characteristic of summer. Peaks in spawning probability occurred 2 mo after peaks in the frequency of the NW winds that characterize winter $(r=0.60, p<0.05$, lag period of 2 ; Fig. 3D).

There was no significant difference between the mean values for individual gamete output (estimated as individual weight loss during a spawning event) in either Perna perna $(0.20 \pm 0.03 \mathrm{~g})$ or Choromytilus meridionalis $\left(0.23 \pm 0.01 \mathrm{~g}, 1\right.$-way ANOVA, $F_{1,23}=0.12$, $\mathrm{p}=0.74$ ), and species within Algoa Bay were pooled for subsequent analysis. Gamete output did not differ significantly among sites on the open coast (1-way
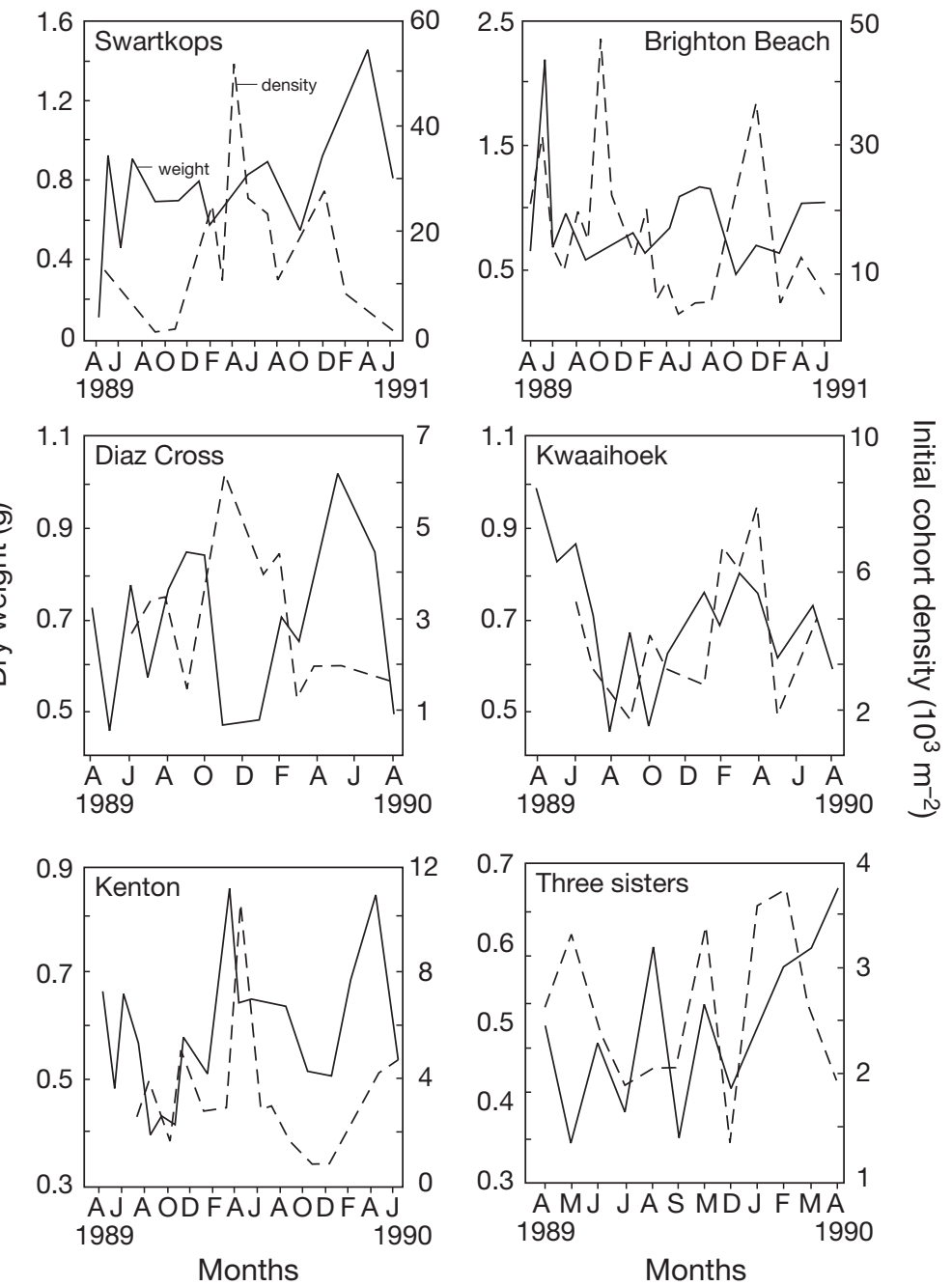

Fig. 2. Perna perna and Choromytilus meridionalis. Variation in density (dashed lines) of mussel recruits (<20 mm shell length) and dry wt (solid lines) of a standard individual of $65 \mathrm{~mm}$. Note: sampling period varied among sites

ANOVA, $\left.F_{3,13}=0.11, \mathrm{p}=0.95\right)$, or among sites in Algoa Bay (1-way ANOVA, $F_{1,6}=1.26, \mathrm{p}=0.34$ ) when tested separately. However, average gamete output was significantly greater (1-way ANOVA, $F_{1,23}=9.06, \mathrm{p}<$ 0.005 ) at sites within Algoa Bay (mean weight loss = $0.32 \pm 0.06 \mathrm{~g}$ per spawning event) than on the open coast $(0.15 \pm 0.02 \mathrm{~g})$.

\section{Recruitment}

Each year, 1 to 2 new cohorts appeared in each population. Each cohort appeared over an extended period that included 2 to 3 peaks in recruitment. The size, timing and duration of these recruitment peaks varied considerably among sites. Cross-correlation analysis of 

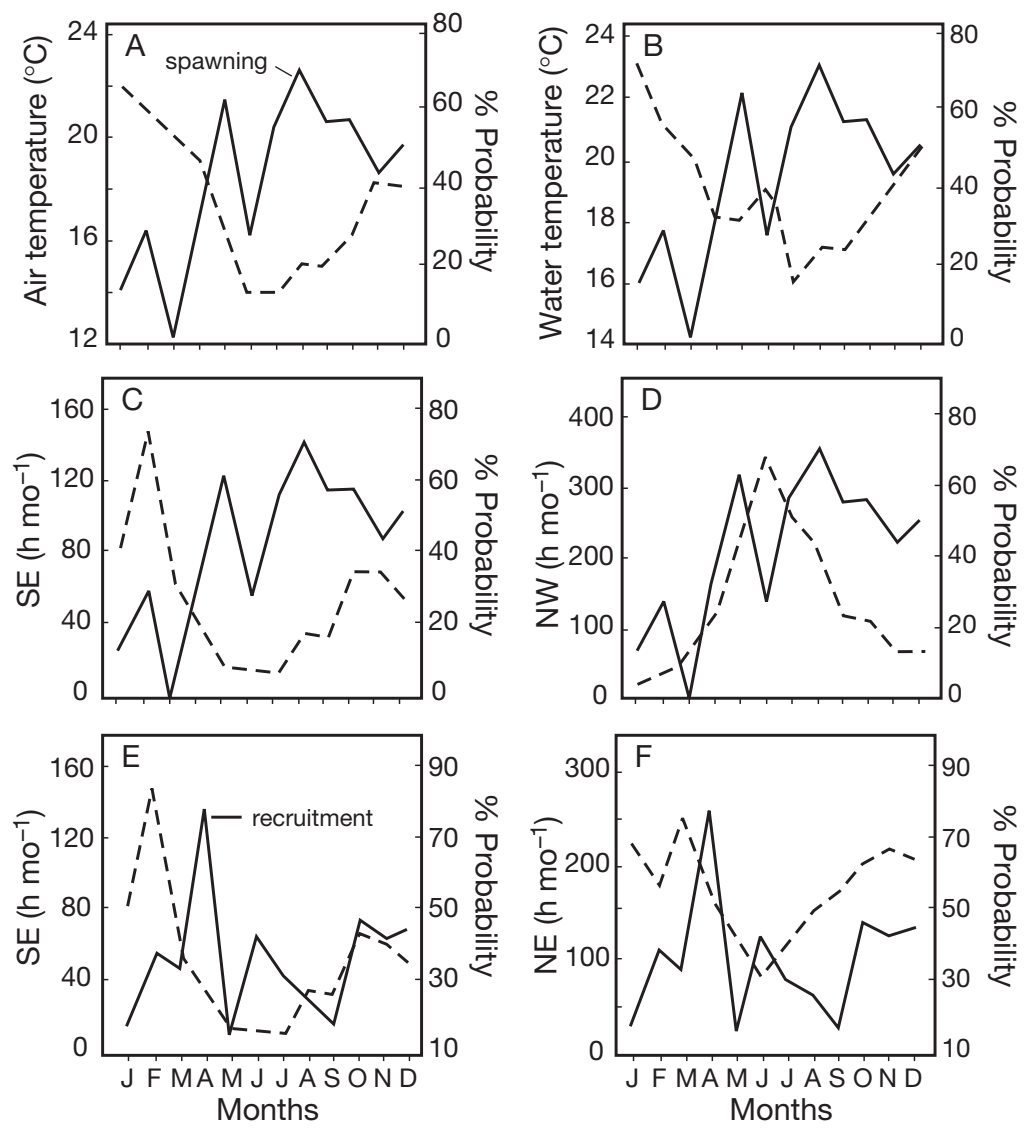

Fig. 3. Perna perna and Choromytilus meridionalis. (A-D) Variation in probability of spawning (solid lines) and environmental conditions (dashed lines) that were significantly cross-correlated with spawning. (E-F) Variation in probability of initial recruitment (i.e. appearance of juvenile cohorts $<10 \mathrm{~mm}$ shell length; solid lines) and environmental conditions (dashed lines). Duration of wind from given direction (SE, NW or NE) indicated in 3C-F. Data pooled over entire sampling period and calculated as means for the months of a hypothetical year

monthly fluctuations in early juvenile density showed that settlement patterns were similar between some sites, but, as with spawning, there was no relationship between the strength of the correlation and the distance between sites (Fig. 4). For the 6 sites at which both spawning and recruitment were measured, periods of protracted spawning were often followed by extended periods of recruitment after 4 to $8 \mathrm{wk}$ (Fig. 2). However, the frequency of sampling was not high enough to examine this relationship critically and cross-correlation analysis could not be used because the lag between spawning and recruitment varied among sites.

Settlement occurred in all months, but the probability of new cohorts appearing (calculated from data for all sites) was greatest in autumn (April) with other peaks in the probability of recruitment in spring (October/November) and, to a lesser extent, winter (July)
(Fig. 3). Cross-correlation analysis between the probability of recruitment and environmental factors showed significant correlations only with the frequencies of SE winds after a 2 mo lag $(\mathrm{r}=0.65, \mathrm{p}<$ 0.05 ) and 1 mo after peaks in the frequency of NE winds ( $\mathrm{r}=0.51, \mathrm{p}<0.05$, Fig. 3). There was a strong relationship between the intensity of spawning prior to the appearance of a new cohort and the maximum density of that cohort $\left(\mathrm{r}^{2}=0.92\right.$, $\mathrm{n}=11, \mathrm{p}<0.001, y=-15714+75249 x)$.

Juvenile growth and mortality were calculated using cohort analysis. For 3 open coast shores (Three Sisters, Kasouga, East Beach), peaks in density were clearer for total recruits (1 to $20 \mathrm{~mm}$ ) than for early juveniles $(<10 \mathrm{~mm})$, and the intensity of recruitment was too low to allow cohorts of early juveniles to be clearly identified or tracked for more than a brief period. These data were not included in further analyses. Because of the extended duration of recruitment into the early juvenile size classes, cohorts were broad rather than discrete and included animals of a range of ages. Growth rate varied for individual cohorts, and regression curves of mean cohort length against time were generally significant (Bonferroni corrected $\alpha$ value of $p<0.003)$. Data for individual cohorts were pooled and a common growth curve calculated as a regression of mean size against age (Fig. 5). This indicated that average size of individuals in a cohort was significantly related to cohort age $(\mathrm{p}<0.001)$ and that newly settled cohorts generally grew quickly, reaching maturity (20 to $25 \mathrm{~mm}$ ) after 7 to $10 \mathrm{mo}$. There was, however, considerable variation among cohorts, leading to much scatter, and mean size at 10 mo varied between approximately 17 and $37 \mathrm{~mm}$.

Densities of cohorts always declined exponentially with time, but regressions of density against age were not significant for some cohorts at open coast sites, probably because low recruitment intensity and merging of age classes made cohort identification and density estimates difficult. Mortality during this period (estimated as decline in cohort density) was high and a common density at age curve plotted from pooled data for all cohorts indicated that only 17 to $29 \%$ of a new cohort survived to 10 mo (Fig. 6). Scatter around this curve was much greater than for the size at age curve, indicating enormous differences in mortality rates among cohorts, especially in the early stages. Al- 


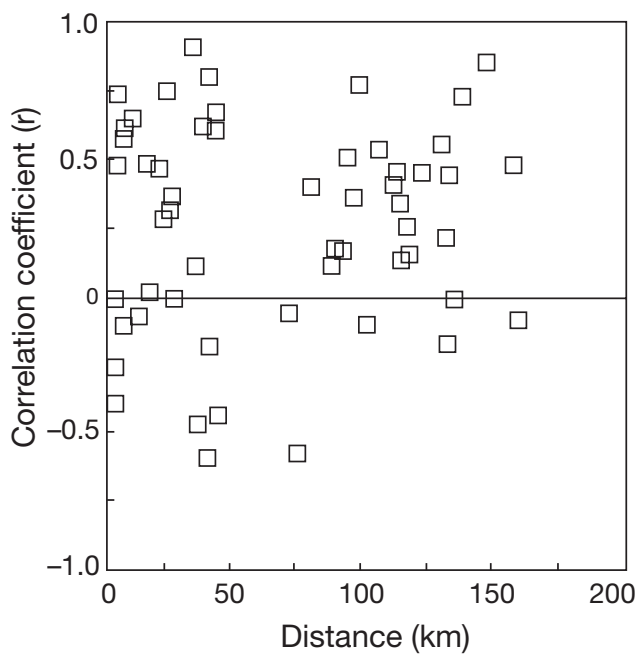

Fig. 4. Perna perna and Choromytilus meridionalis. Variation in strength of correlation ( $\mathrm{r}$ ) between residual monthly fluctuations in recruit density $(<20 \mathrm{~mm})$ at pairs of sites versus distance between sites

though the correlation was significant $(p<0.001)$, the $r^{2}$ value was extremely low $(0.14)$, indicating very low predictability of mortality from age when all cohorts were pooled.

Mean density of early juveniles $(<10 \mathrm{~mm})$ was an order of magnitude greater in Algoa Bay than on the open coast (Table 1) and significantly higher than for the other shore types, with no significant difference between dune rock and sandstone shores on the open coast (1-way ANOVA, $F_{2,619}=34.38, \mathrm{p}<0.0001$, followed by Tukey's test, $\mathrm{p}<0.05)$. However, the initial densities of newly appearing cohorts ranged substan-

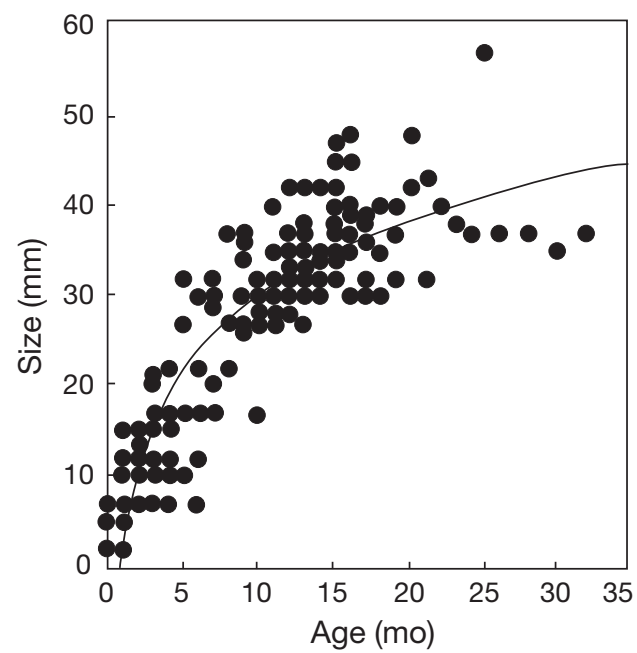

Fig. 5. Perna perna and Choromytilus meridionalis. Relationship between age of cohort and modal size. Data pooled for all cohorts. Curve is logarithmic: $a=2.862, b=11.7961 ; \mathrm{r}^{2}=0.76$, $\mathrm{n}=176, \mathrm{p}<0.001$

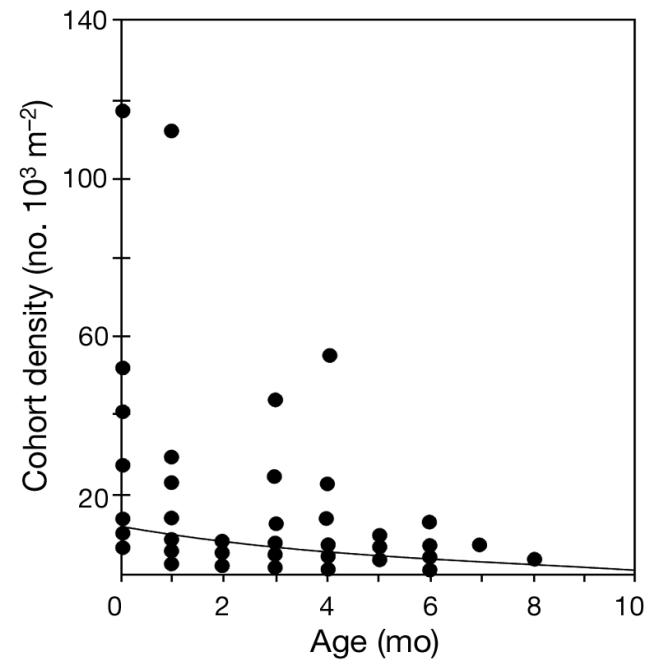

Fig. 6. Perna perna and Choromytilus meridionalis. Relationship between age and density of juvenile mussel cohort. Data pooled for all cohorts under 10 mo old. Curve is logarithmic: $a=11073$, $b=-0.1751 ; \mathrm{r}^{2}=0.14, \mathrm{n}=75, \mathrm{p}<0.001$

tially. Generally, values were 5000 to $60000 \mathrm{~m}^{-2}$, but for 1 cohort initial density was $130000 \mathrm{~m}^{-2}$. Both mortality and growth of recruits were density independent; there were no significant correlations between cohort density and either mean size or \% mortality of individual cohorts after 10 mo on the shore. However, density of a cohort after 10 mo on the shore was closely related to its original density $\left(\mathrm{r}^{2}=0.73, \mathrm{p}<0.001, \mathrm{n}=\right.$ $19, a=28.6745, b=0.0883$ ). Thus, the intensity of recruitment (as estimated by density of early juveniles) accounted for $73 \%$ of the variance in recruitment into the mature adult population (as estimated by density of a $10 \mathrm{mo}$ old cohort). For settlement intensities of $\leq 60000 \mathrm{~m}^{-2}$, there was a significant positive correlation

Table 1. Perna perna and Choromytilus meridionalis. Range and mean $( \pm \mathrm{SE})$ of density of newly settled cohorts (i.e. early recruitment) on Algoa Bay (AB), open coast dune rock (DR) and sandstone (SS) shores. Site abbreviations as in Fig. 1

\begin{tabular}{|lccrrcc|}
\hline $\begin{array}{l}\text { Shore } \\
\text { type }\end{array}$ & Site & $\mathrm{n}$ & $\begin{array}{c}\text { Mean } \\
\left(\text { no. m}^{-2}\right)\end{array}$ & SE & $\begin{array}{c}\text { Range } \\
\left(10 \mathrm{~m}^{-2}\right)\end{array}$ & $\begin{array}{c}\text { Mean of means } \\
\left(\text { no. m}^{-2}\right)\end{array}$ \\
\hline AB & BB & 3 & 35095 & 3523 & $10-118$ & 43457 \\
& SW & 3 & 31495 & 11072 & & \\
& ME & 2 & 63782 & 53598 & & \\
DR & DC & 2 & 8171 & 1974 & $5-11$ & 7901 \\
& KW & 2 & 7563 & 416 & & \\
& KE & 2 & 7968 & 2806 & & \\
SS & CP & 2 & 12213 & 3296 & $6-16$ & 9705 \\
& KA & 1 & 8789 & - & & \\
& SB & 3 & 6521 & 259 & & \\
& EB & 2 & 8501 & 1824 & & \\
& RU & 1 & 12501 & - & & \\
\hline
\end{tabular}


between spawning intensity and the density of new cohorts $\left(\mathrm{r}^{2}=0.92, \mathrm{p}<0.001, \mathrm{n}=11\right)$, but not between spawning intensity and cohort density at $10 \mathrm{mo}(\mathrm{p}>$ 0.05). We could not examine this relationship for higher recruitment densities, as the site with settlement of $130000 \mathrm{~m}^{-2}$ was not sampled for spawning.

Multiple regression analysis for the 6 sites sampled for spawning indicated that spawning intensity (SI), recruitment intensity (RI), growth $(\mathrm{G})$, and mortality prior to maturity (M) collectively accounted for $76 \%$ of the variation in recruitment into the adult population (i.e. density of 10 mo old cohorts)

$$
\begin{gathered}
y=15410-19980 x_{(\mathrm{SI})}+0.3380 x_{(\mathrm{RI})}+113 x_{(\mathrm{G})}-155 x_{(\mathrm{M})} \\
\mathrm{r}^{2}=0.76, \mathrm{SE}=1077
\end{gathered}
$$

The Durban Watson statistic was 2.78, indicating that the independent variables were not autocorrelated $(\mathrm{p}<0.01, \mathrm{n}=23)$.

\section{Population size-structure and abundance}

There were also differences in adult size composition, longevity (Table 2, Fig. 7) and abundances (Fig. 8) among shore types. Populations in Algoa Bay supported high densities of small individuals (Fig. 7A-C) with short life expectancies. Within Algoa Bay, mean longevity of Perna perna was estimated to be $<1$ yr at Brighton Beach, while Choromytilus
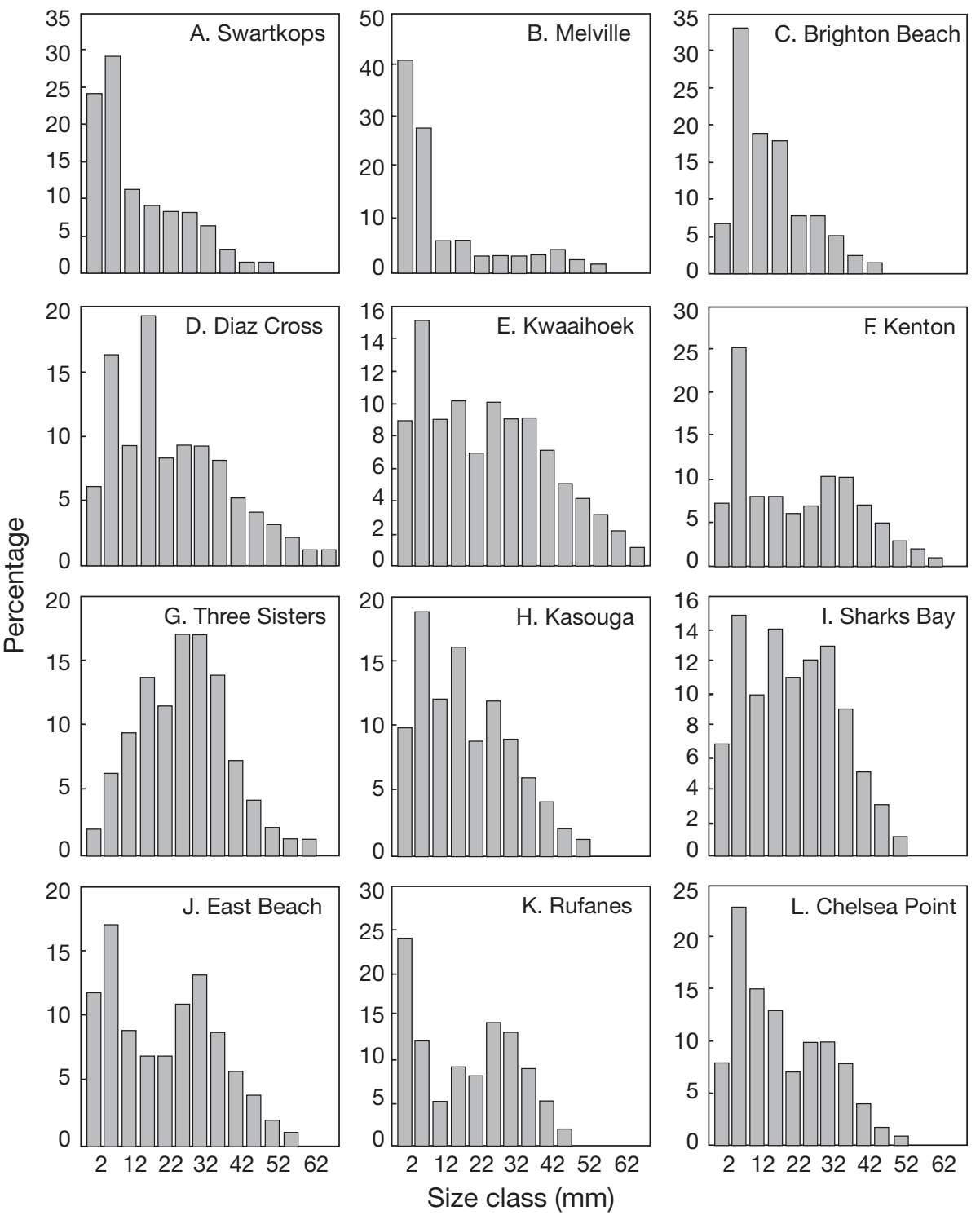

Fig. 7. Perna perna and Choromytilus meridionalis. General shell length frequency distribution for each mussel population based on pooled data for each month. Monthly sample sizes were approximately: 1000 for Algoa Bay sandstone shores (A-C); 600 for open coast dune rock shores $(\mathrm{D}-\mathrm{G}) ; 500$ for open coast sandstone shores $(\mathrm{H}-\mathrm{L})$. Mid-points of $4 \mathrm{~mm}$ size classes are shown 
meridionalis lived much longer at Swartkops (1 to $2 \mathrm{yr}$ ) and Melville (2 to $3 \mathrm{yr}$ ). On the open coast, sandstone shores generally had bimodal populations (Fig. 7H-L), with adult cohort sizes and longevity similar to Algoa Bay. Dune rock shores had low densities of large individuals (Fig. 7D-G), and longevity of $P$. perna was much higher (2 to $4 \mathrm{yr}$ ). Despite the bias of C. meridionalis occurring only in Algoa Bay, mussel longevity on dune rock shores was markedly greater than on sandstone shores either in Algoa Bay or on the open coast (Table 2).

The majority of shores showed huge variations in total mussel density, and in the densities of recruits $(<20 \mathrm{~mm})$ and adults $(>20 \mathrm{~mm})$ when examined separately (Fig. 8). Mean densities were compared using data pooled for all months for each site separately, and varied significantly among the 3 shore types (1-way ANOVA on log transformed data followed by Tukey's
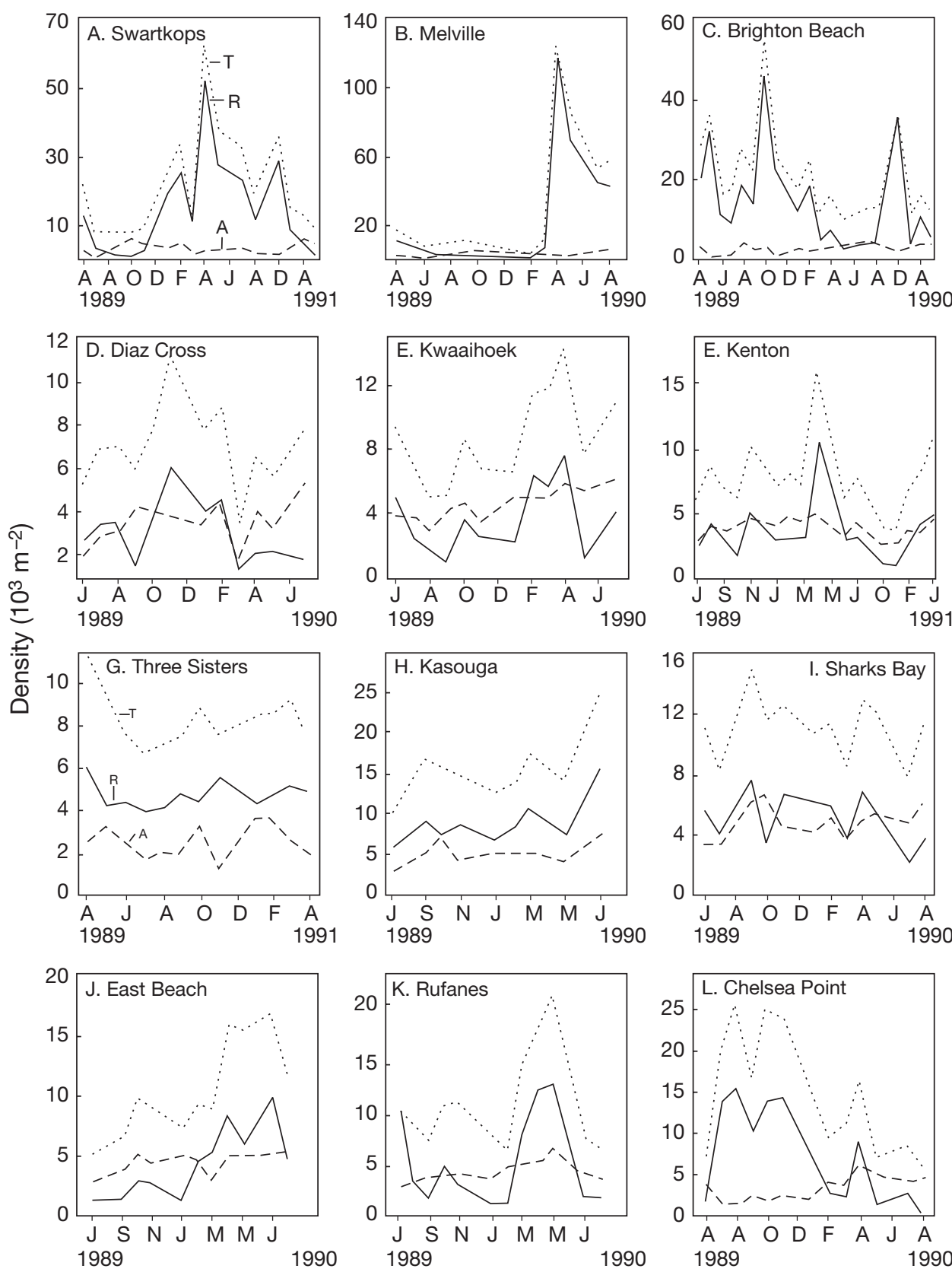

Fig. 8. Perna perna and Choromytilus meridionalis. Variation in density of mussel recruits of 0 to $19 \mathrm{~mm}$ shell length (R: solid line), adults $>20 \mathrm{~mm}$ (A: dashed line) and total mussel density (T: dotted line) at each site. (A-C) Algoa Bay sandstone shores; (D-G) open coast dune rock shores; $(\mathrm{H}-\mathrm{L})$ open coast sandstone shores 
Table 2. Perna perna and Choromytilus meridionalis. Maximum modal size and mean longevity $( \pm \mathrm{SE})$ of adult cohorts estimated from growth curves for newly settled cohorts at each site. Site abbreviations as in Fig. 1. Densities were too low to allow tracking of cohorts at Sites KA, EB and TS. Shore types are: Algoa Bay sandstone $(\mathrm{AB})$; open coast dune rock (DR); open coast sandstone (SS)

\begin{tabular}{|c|c|c|c|c|c|}
\hline $\begin{array}{l}\text { Shore } \\
\text { type }\end{array}$ & Site & Cohort & $\begin{array}{l}\text { Max. } \\
\text { modal size } \\
(\mathrm{mm})\end{array}$ & $\begin{array}{c}\text { Longevity } \\
\text { (mo) }\end{array}$ & $\begin{array}{c}\text { Mean } \\
\text { longevity } \\
(\mathrm{mo})\end{array}$ \\
\hline $\mathrm{AB}$ & SW & $\begin{array}{c}\text { C1 } \\
\text { C2 } \\
\text { C3 } \\
\text { Mean } \\
\text { C1 } \\
\text { C2 } \\
\text { C3 } \\
\text { Mean } \\
\text { C1 } \\
\text { C2 } \\
\text { Mean }\end{array}$ & 35 & $\begin{array}{c}9 \\
14 \\
11 \\
11 \pm 3 \\
13 \\
15 \\
25 \\
18 \pm 6 \\
19 \\
37 \\
28 \pm 13\end{array}$ & 18.18 \\
\hline DR & $\begin{array}{l}\text { DC } \\
\\
\text { KW } \\
\text { KE } \\
\text { TS }\end{array}$ & $\begin{array}{c}\text { C1 } \\
\text { C2 } \\
\text { Mean } \\
\text { C1 } \\
\text { C1 } \\
-\end{array}$ & $\begin{array}{l}57 \\
40 \\
37\end{array}$ & $\begin{array}{c}21 \\
27 \\
24 \pm 4 \\
44 \\
34 \\
-\end{array}$ & 30 \\
\hline SS & $\begin{array}{l}\text { SB } \\
\text { RU } \\
\text { KA } \\
\text { EB }\end{array}$ & $\begin{array}{c}\text { C1 } \\
\text { C2 } \\
\text { Mean } \\
\text { C2 } \\
\text { C1 } \\
- \\
-\end{array}$ & $\begin{array}{l}32 \\
34 \\
30 \\
35\end{array}$ & $\begin{array}{c}26 \\
10 \\
18 \pm 11 \\
11 \\
18 \\
- \\
-\end{array}$ & 16.6 \\
\hline
\end{tabular}

tests. $F_{2,619}=34.38,14.24$, and 102.23 for recruit, adult and total density respectively, $\mathrm{p}<0.001$ in all cases). Total density and recruit density declined from Algoa Bay to open coast sandstone to open coast dune rock. Adult densities were lower on open coast dune rock than the other 2 shore types, and appeared to fluctuate less (Fig. 8).

Thus, the sandstone shores of Algoa Bay were sites of high recruitment leading to high densities of adults, but this was associated with low longevity and adults were small, i.e. these were sites of high density and rapid turnover. On the open coast, sandstone shores were characterized by low recruitment and this was associated with low longevity; adults were again small. Adult densities sometimes showed extreme fluctuations but, paradoxically, mean adult density was high. Open coast dune rock shores were sites of lowest recruitment and lowest adult densities. However, longevity and adult size were high, i.e. low density and low turnover. Thus, populations on open coast dune rock shores tended to be more stable than on other shore types. This was supported by Kruskal-Wallis tests used to examine the effect of month on estimates of adult density at each site. These tests showed significant $(p<0.05)$ effects of sampling date on adult densities for 7 of the 8 sandstone shores (Algoa Bay and open coast), but only half the 4 dune rock shores.

\section{DISCUSSION}

Mesoscale differences in mussel populations between Algoa Bay and the open coast and between rock types on the open coast were very clear, even when 2 species of mussels were considered together. These differences existed in mussel population structure and the magnitude of spawning and recruitment events, but not in the timing of events.

All shores showed trickle spawning and continuous recruitment throughout the year, but intensive spawning was more likely in autumn-spring and was negatively correlated with the higher air and sea temperatures and the SE winds of summer. This only partially matches the pulsing of chlorophyll concentrations in inshore waters, which are higher in spring (September to November) and autumn (March to May) (Brown 1992). The probability of spawning was high in spring and autumn, but also in winter, when chlorophyll levels are low. There was no synchrony of spawning among sites at the temporal resolution we examined.

Spawning in mussels is influenced by extrinsic factors such as temperature (see Seed 1976) that vary on scales too large to explain differences in the timing of spawning among these populations, and the most likely explanation is variation in food supply (Himmelman 1975, Starr et al. 1990). If timing is affected by phytoplankton concentration, then small-scale $(<5 \mathrm{~km})$ differences must exist in concentrations or in water flow over the mussel beds. Menge et al. (1997) found that $10 \mathrm{~km}$-scale between-site variability rather than within-shore differences on scales of 10 s or 100 s of metres accounted for most of the variance in chlorophyll a levels in intertidal water. However, on the south coast of South Africa, dense patches of surf-diatoms form on small $(100 \mathrm{~m})$ scales due to temporary winddriven aggregation, rather than local bloom formation (Talbot \& Bate 1988). Mussel growth on wave-exposed shores is about double that on sheltered shores (McQuaid \& Lindsay 2000). Interactions between phytoplankton patchiness and differences in average water flux among shores could produce the observed variations in the timing of spawning. Recruitment was similarly poorly correlated with environmental factors, but was more likely in spring (October to November) and autumn (April) and showed some correlation with $\mathrm{SE}$ and NE winds.

While there were no patterns among shore types in the timing of spawning and recruitment, there were 
consistent differences in the magnitude of events. Algoa Bay had spawning intensity that was twice as high and recruitment an order of magnitude greater than on the open coast. The densities of new cohorts were also significantly correlated with the intensity of the previous spawning event in the same population, which accounted for $>70 \%$ of the variation in new cohort density.

Correlation between spawning and recruitment intensity has several possible explanations. Factors that favour recruitment could also favour spawning: high water flux could increase food supply (favouring gonad development) and larval flux (increasing larval supply); or, conditions that favour adults (resulting in high spawning intensity) may also favour settlers (our recruits were relatively old and post-settlement mortality could differ strongly among shores). Alternatively, correlation could imply a causal relationship with limited dispersal linking spawning and recruitment. A review by Swearer et al. (2002) indicates that self-recruitment occurs widely, so that larval exchange rates may be overestimated (Cowen et al. 2000), and such effects will clearly be driven by the interaction of larval behaviour and local hydrodynamics. Modelling by Verdier-Bonnet et al. (1997) suggests that under normal wind conditions in their study area, no larval mixing will occur between polychaete populations in 2 bays only $1.6 \mathrm{~km}$ apart. In our study area, low exchange between the bay and the open coast (i.e. retention within the bay) seems possible, but recruitment of larvae spawned by the same population is highly unlikely at scales $<5 \mathrm{~km}$.

If bay/open coast exchange is limited, then poor recruitment on the open coast could be linked to both the loss of larvae through advective losses/dilution and to low spawning output. Low spawning intensity reduces the pool of larvae for all shores on the open coast, while high spawning intensity in Algoa Bay must at least produce a large initial pool of zygotes, and high recruitment implies little advective loss out of the bay. In South Africa, densities of recruits are generally very low compared to northern temperate areas (Table 3). In the Transkei region, 300 $\mathrm{km}$ east of our sites, overexploitation of mussels by humans results in extremely sparse adult populations and recruit densities that are even lower (Lasiak \& Barnard 1995, Harris et al. 1998), so low recruitment mirrors the absence of large breeding stocks on scales of 1 to $100 \mathrm{~km}$. The correlation between spawning and recruitment on the same shore is difficult to inter- pret, and only indicates that shores with high spawning tend to have high recruitment.

Synchronisation of settlement within populations was poor, reducing the intensity of intraspecific interactions; therefore, pre-settlement effects should be relatively important in structuring these populations. Mortality varied enormously among cohorts, but growth and mortality of newly settled cohorts were density independent, with an exponential decline in density with age and $<30 \%$ of new recruits reaching maturity. Mortality rates for primary settlers are probably very much higher.

Greater recruitment in Algoa Bay was reflected in adult populations. Adult densities were much higher within Algoa Bay (sandstone shores, AS), and decreased significantly from open coast sandstone (OS) to open coast dune rock (OD). Mussel longevity showed almost the reverse pattern and decreased $\mathrm{OD}>\mathrm{AS}=\mathrm{OS}$. This was likely to be due to intraspecific competition for food or space, but we did not test this. The shores with the heaviest recruitment rates had the smallest adults (see also Petraitis 1990). Thus, Algoa Bay shores were sites of high densities and high turnover. On the open coast, dune rock shores had low densities and turnover, while sandstone shores had high densities but low turnover.

The predictions of Roughgarden et al. (1985) for 2 scenarios of contrasting settlement intensity on the high shore fit the findings of this study well. High recruitment shores (Algoa Bay) have mussels of a narrow range of sizes and ages, while open coast dune

Table 3. Perna perna and Choromytilus meridionalis. Published values of mussel recruit densities. Size classes differ among studies, but all are early recruits. Values extrapolated to no. $\mathrm{m}^{-2} \mathrm{mo}^{-1}$ where necessary. Exceptions are one-off surveys, giving recruitment accumulated over unknown periods (Petersen 1984, McGrath \& King 1991) and this study, which gives densities of new cohorts accumulated over 2 to 3 mo. $1^{\circ}$ and $2^{\circ}$ are early/late plantigrades, where separated

\begin{tabular}{|lccl|}
\hline Location & Maximum & Minimum & Source \\
\hline Ireland & $7 \times 10^{6}$ & 60000 & McGrath \& King (1991) \\
East UK & $2 \times 10^{6}$ & 200000 & Seed (1969) \\
Spain & $2 \times 10^{6}\left(2^{\circ}\right)$ & $1 \times 10^{6}$ & Caceres-Martinez et al. (1993) \\
Spain & $890000\left(1^{\circ}\right)$ & 44000 & Caceres-Martinez et al. (1993) \\
Ireland & 840000 & 60000 & McGrath et al. (1988) \\
East UK & 700000 & 100000 & Seed (1969) \\
West UK & 300000 & 50000 & Dare (1976) \\
US Pacific & 300000 & 200 & Petersen (1984) \\
US Atlantic & 250000 & 25000 & Petraitis (1991) \\
Baltic & 132000 & 65000 & Kautsky (1982) \\
S. Africa & 130000 & 5000 & Present study (exceptional) \\
US Atlantic & 65000 & 25000 & Petraitis (1990) \\
S. Africa & 60000 & 5000 & Present study (normal) \\
S. Africa & $6000\left(2^{\circ}\right)$ & 300 & Lasiak \& Barnard (1995) \\
East Canada & 5400 & 2000 & Hunt \& Scheibling (1996) \\
S. Africa & $4800\left(1^{\circ}\right)$ & 170 & Lasiak \& Barnard (1995) \\
\hline
\end{tabular}


rock shores have the lowest recruitment rates and lower densities with a wider range of ages. Open coast sandstone shores are intermediate. The same differences in population densities and structure occur between low shore and high shore populations on the same shore. Upper shore populations include scattered clumps of mussels with much free space, while mussels normally blanket the lower shore (authors' pers. obs.). Again, these differences mirror an upshore decrease in settlement rates (authors' pers. obs. and unpubl. data). So, whatever the mechanism invoked to explain differences in recruitment rate, the effects of settlement intensity and the link with population structure seem valid over a wide range of spatial scales: within shore, among shores, bays/open coast, biogeographic.

Differences in recruitment among shore types could be explained by post-settlement mortality, and the 2 rock types differ in various ways; however, there were no obvious differences between sandstone shores in Algoa Bay and on the open coast, and larval supply is a more likely explanation (e.g. Chiba \& Noda 2000, Dobretsov \& Wahl 2001). Dispersal and distribution of planktonic larvae, or even postlarvae (Committo et al. 1995a,b), of benthic organisms are generally believed to be controlled by water movement at most scales under field conditions (e.g. Pineda 1991, Pedrotti \& Fenaux 1992, Alexander \& Roughgarden 1996, Shanks \& Brink 2005).

Circulation and water exchange in Algoa Bay are strongly wind forced (Goschen \& Schumann 1994). The south coast of South Africa is powerfully influenced by the southward flowing Agulhas Current. Warm water intrusions into Algoa Bay, originating in meanders of the Agulhas Current, occur on average 3 to 4 times a year (Goschen \& Schumann 1988), and cold water intrusions of upwelled water resulting from easterly winds occur during summer (Beckley 1983, Schumann et al. 1988, Goschen \& Schumann 1995). When the bay is not being flushed by such a large-scale exchange with offshore waters, it is possible that larvae will be retained within the bay due to hydrographic conditions (cf. Sammarco \& Andrews 1989, Black 1993). Levin (1983) suggested that few polychaete larvae leave Mission Bay in California, but that is an enclosed bay. Algoa Bay is a very open, log-spiral or 'half-heart' bay (Fig. 1), and retention of larvae would depend on hydrography, not a narrow link to the sea.

Two main points emerge from this study: (1) Settlement/recruitment rates were lower than in most northern temperate studies and showed little synchronisation of settlement within sites. As a result, recruitment of the relatively sparse new cohorts was protracted rather than strongly pulsed. Density-independent growth and mortality of recruits imply that pre-settlement effects on population dynamics will be par- ticularly important to population regulation. This is supported by the significant relationship between the size of newly settled cohorts and later recruitment into the parent population. (2) Mesoscale differences in recruitment between Algoa Bay and the open coast are associated with differences in population structure and adult longevity. These could be explained by postsettlement mortality, but larval supply is a more plausible explanation. This suggests relatively limited larval exchange between Algoa Bay and the open coast (i.e. mesoscale retention of larvae), which is also one possible explanation for a significant correlation between spawning and recruitment. The absence of synchrony in either spawning or recruitment, together with the differences in magnitude of these factors among shore types, suggests that shores inside and outside Algoa Bay are demographically almost independent, with relatively weak links. Shores inside and outside the bay thus seem to function as partially isolated elements of a coastal metapopulation, connected by limited larval exchange. Finally, there were differences in population structure, longevity and turnover between dune rock and sandstone shores on the open coast that are not explicable in terms of recruitment intensity.

\section{LITERATURE CITED}

Alexander SE, Roughgarden J (1996) Larval transport and population dynamics of intertidal barnacles: a coupled benthic/oceanographic model. Ecol Monogr 66:259-275

Beckley LE (1983) Sea-surface temperature variability around Cape Receife, South Africa. S Afr J Sci 79:436-438

Bertness MD, Gaines SD, Stephens EG, Yund PO (1992) Components of recruitment in populations of the acorn barnacle, Semibalanus balanoides (Linneaus). J Exp Mar Biol Ecol 156:199-215

Black KP (1993) The relative importance of local retention and inter-reef dispersal of neutrally buoyant material on coral reefs. Coral Reefs 12:43-53

Booth DJ, Brosnan DM (1995) The role of recruitment dynamics in rocky shore and coral reef fish communities. Adv Ecol Res 26:309-385

Branch GM (1984) Competition between marine organisms: ecological and evolutionary implications. Oceanogr Mar Biol Annu Rev 22:429-593

Broitman BR, Navarrete SA, Smith F, Gaines SD (2001) Geographic variation of southeastern Pacific intertidal communities. Mar Ecol Prog Ser 224:21-34

Brown PC (1992) Spatial and seasonal variation in chlorophyll distribution in the upper $30 \mathrm{~m}$ of the photic zone in the southern Benguela/Agulhas ecosystem. S Afr J Mar Sci 12:515-525

Caceres-Martinez J, Robledo JAF, Figueras A (1993) Settlement of mussels Mytilus galloprovincialis on an exposed rocky shore in Ría de Vigo, NW Spain. Mar Ecol Prog Ser 93:195-198

Caley MJ, Carr MH, Hixon MA, Hughes TP, Jones GP, Menge BA (1996) Recruitment and the local dynamics of open marine populations. Annu Rev Ecol Syst 27:477-500 
Cassie SE (1954) Some uses of probability paper in the analysis of size frequency distributions. Aust J Mar Freshw Res 5:513-522

Chiba S, Noda T (2000) Factors maintaining topographyrelated mosaic of barnacle and mussel on a rocky shore. J Mar Biol Assoc UK 80:617-622

Commito JA, Currier CA, Kane LR, Reinsel KA, Ulm IM (1995a) Dispersal dynamics of the bivalve Gemma gemma in a patchy environment. Ecol Monogr 65:1-20

Commito JA, Thrush SF, Pridmore RD, Hewitt JE, Cummings VJ (1995b) Dispersal dynamics in a wind-driven benthic system. Limnol Oceanogr 40:1513-1518

Connell JH (1985) Consequences of variation in initial settlement vs. post-settlement mortality in rocky intertidal communities. J Exp Mar Biol Ecol 93:11-45

Connolly SR, Roughgarden J (1998) A latitudinal gradient in northeast intertidal community structure: evidence for an oceanographically based synthesis of marine community theory. Am Nat 151:311-326

Connolly SR, Menge BA, Roughgarden J (2001) A latitudinal gradient in recruitment of invertebrates in the northeast Pacific Ocean. Ecology 82:1799-1813

Cowen RK, Lwiza KMM, Sponaugle S, Paris CB, Olson DB (2000) Connectivity of marine populations: open or closed? Science 287:857-859

Dare PJ (1976) Settlement growth and poduction of the mussel Mytilus edulis, in Morecambe Bay, England. Fish Investig Ser II 28:1-25

Dobretsov S, Wahl M (2001) Recruitment preferences of blue mussel spat (Mytilus edulis) for different substrata and microhabitats in the White Sea. Hydrobiologia 445:27-35

Dunstan FDJ (1993) Time series analysis. In: Fry JC (ed) Biological data analysis. A practical approach. Oxford University Press, Oxford, p 243-290

Gaines SD, Bertness MD (1992) Dispersal of juveniles and variable recruitment in sessile marine species. Nature 360: $579-580$

Goschen WS, Schumann EH (1988) Ocean current and temperature structures in Algoa Bay and beyond in November 1986. S Afr J Mar Sci 7:101-116

Goschen WS, Schumann EH (1994) An Agulhas current intrusion into Algoa Bay during August 1988. S Afr J Mar Sci 14:45-57

Goschen WS, Schumann EH (1995) Upwelling and the occurrence of cold water around Cape Receife, Algoa Bay, South Africa. S Afr J Mar Sci 16:57-67

Griffiths RJ (1977) Reproductive cycles in littoral populations of Choromytilus meridionalis (Kr.) and Aulacomya ater (Molina) with a quantitative assessment of gamete production in the former. J Exp Mar Biol Ecol 30:53-71

Griffiths CL, King JA (1979) Energy expended on growth and gonad output in the ribbed mussel Aulacomya ater. Mar Biol 53:217-222

Guichard F, Halpin PM, Allison GW, Luchenco J, Menge BA (2003) Mussel disturbance dynamics: signatures of oceanographic forcing from local interactions. Am Nat 161:879-904

Harris JM, Branch GM, Elliott BL, Currie B, Dye A, McQuaid CD, Tomalin B, Velasquez C (1998) Spatial and temporal variability in recruitment of intertidal mussels around the coast of southern Africa. S Afr J Zool 33:1-11

Himmelman JH (1975) Phytoplankton as a stimulus for spawning in three marine invertebrates. J Exp Mar Biol Ecol 20:199-214

Hunt HL, Scheibling RE (1996) Physical and biological factors influencing mussel (Mytilus trossulus, M.edulis) settle- ment on a wave exposed rocky shore. Mar Ecol Prog Ser 142:135-145

Jarrett JN, Pechenik JA (1997) Temporal variation in cyprids quality and juvenile growth capacity for an intertidal barnacle. Ecology 78:1262-1265

Kautsky N (1982) Quantitative studies on gonad cycle, fecundity, reproductive output and recruitment in a Baltic Mytilus edulis population. Mar Biol 68:143-160

Keough MJ (1983) Patterns of recruitment of sessile invertebrates in two subtidal habitats. J Exp Mar Biol Ecol 66: 213-245

Keough MJ, Downes BJ (1982) Recruitment of marine invertebrates: the role of active larval choices and early mortality. Oecologia 54:348-352

Koh LL, Riordan RMO, Lee WJ (2005) Sex in the tropics: reproduction of Chthamalus malayensis Pilsbury (Class Cirripedia) at the equator. Mar Biol 147:121-133

Lalli CM, Parsons TR (1993) Biological oceanography: an introduction. Pergammon Press, Oxford

Lasiak TA, Barnard TCE (1995) The recruitment of the brown mussel Perna perna onto natural substrata: a refutation of the primary/secondary settlement hypothesis. Mar Ecol Prog Ser 120:147-153

Levin LA (1983) Drift tube studies of Bay-Ocean water exchange and implications for larval dispersal. Estuaries 6:364-371

Marshall DJ, McQuaid CD (1993) Differential physiological and behavioural responses of the intertidal mussels, Choromytilus meridionalis (Kr.) and Perna perna L., to exposure to hypoxia and air: a basis for spatial separation. J Exp Mar Biol Ecol 171:225-237

McGrath D, King PA (1991) Settlement of mussels, Mytilus edulis L. on wave-exposed shores in Irish waters: a survey. Proc R Ir Acad Sect B Biol Geol Chem Sci 91:49-58

McGrath D, King PA, Gosling EM (1988) Evidence for the direct settlement of Mytilus edulis larvae on adult mussel beds. Mar Ecol Prog Ser 47:103-106

McQuaid CD, Lawrie SM (2005) Supply-side ecology of the brown mussel Perna perna: an investigation of spatial and temporal variation in, and coupling between, gamete release and larval supply. Mar Biol 147:955-963

McQuaid CD, Lindsay TL (2000) The effects of wave exposure on growth and mortality rates of the mussel Perna perna: bottom-up regulation of intertidal populations. Mar Ecol Prog Ser 206:147-154

McQuaid CD, Lindsay JR, Lindsay TL (2000) Interactive effects of wave exposure and tidal height on population structure of the brown mussel Perna perna. Mar Biol 137: 925-932

Menge BA (1991) Relative importance of recruitment and other causes of variation in rocky intertidal community structure. J Exp Mar Biol Ecol 146:69-100

Menge BA, Sutherland JP (1987) Community regulation: variation in disturbance, competition, and predation in relation to environmental stress and recruitment. Am Nat 130: 730-757

Menge BA, Daley BA, Wheeler PA, Strub PT (1997) Rocky intertidal oceanography: an association between community structure and nearshore phytoplankton concentration. Limnol Oceanogr 42:57-66

Menge BA, Lubchenco J, Bracken MES, Chan F and 9 others (2003) Coastal oceanography sets the pace of rocky intertidal community dynamics. Proc Natl Acad Sci 1000: 12229-12234

Pedrotti AM, Fenaux L (1992) Dispersal of echinoderm larvae in a geographical area marked by upwelling (Ligurian Sea, NW Mediterranean). Mar Ecol Prog Ser 86:217-227 
Petersen JH (1984) Larval settlement behaviour in competing species: Mytilus californianus Conrad and M. edulis L. J Exp Mar Biol Ecol 82:147-159

Petraitis PS (1990) Direct and indirect effects of predation, herbivory and surface rugosity on mussel recruitment. Oecologia 83:405-413

Petraitis PS (1991) Recruitment of the mussel Mytilus edilus L. on sheltered and exposed shores in Maine, USA. J Exp Mar Biol Ecol 147:65-80

Pineda J (1991) Predictable upwelling and the shoreward transport of planktonic larvae by internal tidal bores. Science 253:548-551

Pineda J (2000) Linking larval settlement to larval transport: assumptions, potentials, and pitfalls. Oceanogr East Pac 1: 84-105

Porri F, McQuaid CD, Radloff S (2006) Spatio-temporal variability of larval abundance and settlement of Perna perna: differential delivery of mussels. Mar Ecol Prog Ser 315: 141-150

Poulin E, Palma AT, Leiva G, Hernández E, Martínez P, Navarrete SA, Castilla JC (2002) Temporal and spatial variation in the distribution of epineustonic competent larvae of Concholepas concholepas along the central coast of Chile. Mar Ecol Prog Ser 229:95-104

Raimondi PT (1990) Patterns, mechanisms, consequences of variability in settlement and recruitment of an intertidal barnacle. Ecol Monogr 60:283-309

Roughgarden J, Iwasa Y, Baxter C (1985) Demographic theory for an open marine population with space-limited recruitment. Ecology 66:54-67

Sammarco PW, Andrews JC (1989) The Helix experiment: differential localized dispersal and recruitment patterns in Great Barrier Reef corals. Limnol Oceanogr 34: 896-912

Schumann EH, Ross GJB, Goschen WS (1988) Cold water events in Algoa Bay and along the Cape south coast, South Africa, in March/April 1987. S Afr J Sci 84:579-584

Seed R (1969) The ecology of Mytilus edulis L. (lamellibranchiate) on exposed rocky shores. I. Breeding and settlement. Oecologia 3:277-316

Seed R (1976) Ecology. In: Bayne BL (ed) Marine mussels: their ecology and physiology. Cambridge University Press, Cambridge, p 13-65

Editorial responsibility: Roger Hughes (Contributing Editor), Bangor, UK
Seed R, Suchanek TH (1992) Population and community ecology of Mytilus. In: Gosling E (ed) The mussel Mytilus: ecology, physiology, genetics and culture. Elsevier, Amsterdam, p 87-157

Shanks AL, Brink L (2005) Upwelling, downwelling, and cross-shelf transport: test of a hypothesis. Mar Ecol Prog Ser 302:1-12

Starr M, Himmelman JH, Therriault JC (1990) Direct coupling of marine invertebrate spawning with phytoplankton blooms. Science 247:1071-1074

Suchanek TH (1978) The ecology of Mytilus edulis in exposed rocky intertidal communities. J Exp Mar Biol Ecol 31: 105-120

Sutherland JP (1990) Recruitment regulates demographic variation in a tropical intertidal barnacle. Ecology 71: 955-972

Swearer SE, Shima JS, Hellberg ME, Thorrold SR and 6 others (2002) Evidence of self-recruitment in demersal marine populations. Bull Mar Sci 70:251-271

Talbot MMB, Bate GC (1988) Distribution patterns of the surf diatom Anaulis birostratus in an exposed surfzone. Estuar Coast Shelf Sci 26:137-153

Thorrold SR, Jones GP, Hellberg ME, Burton RS, Swearer SE, Neigel JE, Morgan SG, Warner RR (2002) Quantifying larval retention and connectivity in marine populations with artificial and natural markers: Can we do it right? Bull Mar Sci 70:291-308

Underwood AJ, Fairweather PG (1989) Supply-side ecology and benthic marine assemblages. Trends Ecol Evol 4:16-20

Underwood AJ, Keough MJ (2001) Supply-side ecology: the nature and consequences of variations in recruitment of intertidal organisms. In: Bertness MD, Gaines SD, Hay ME (eds) Marine community ecology. Sinauer Associates, Sunderland, MA

Van Erkom Schurink C, Griffiths CL (1991) A comparison of reproductive-cycles and reproductive output in four southern African mussel species. Mar Ecol Prog Ser 76:123-134

Verdier-Bonnet C, Carlotti F, Rey C, Bhaud M (1997) A model of larval dispersion coupling wind-driven currents and vertical larval behaviour: application to the recruitment of the annelid Owenia fusiformis in Banyuls Bay, France. Mar Ecol Prog Ser 160:217-231

Submitted: September 21, 2005; Accepted: May 10, 2006

Proofs received from author(s): November 15, 2006 